\title{
Corporate governance disclosures in the annual reports of Nigerian banks
}

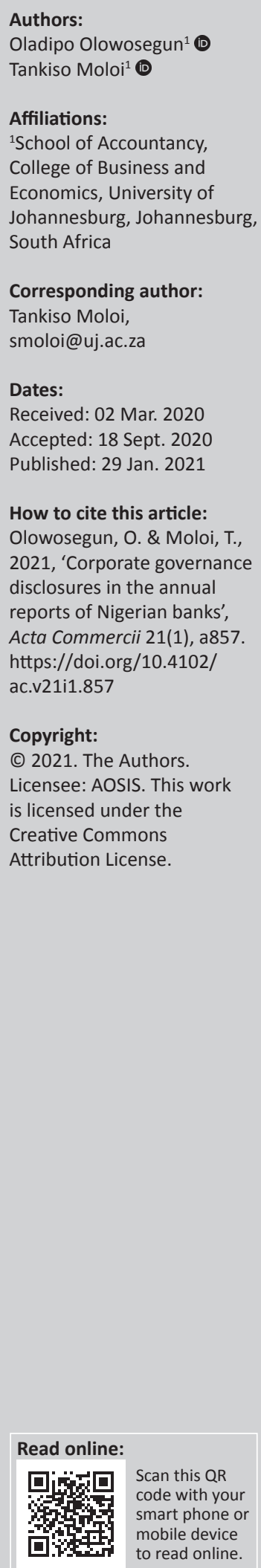

Orientation: Several breaches continue to occur in Nigeria's banking sector even with the litany of regulation put in place. These regulations require that banks disclose certain types of information, for accountability and transparency.

Research purpose: To determine the extent of corporate governance disclosures in annual reports of Nigerian banks taking into cognisance the provisions of laws and codes applicable to Nigerian banks as well as acclaimed national codes and international guiding principles on corporate governance.

Motivation for the study: Disclosures of corporate governance practices in the annual reports are a subtle indication of the level of compliance with provisions of relevant laws and codes.

Research design, approach, and method: The study employed the qualitative content analysis that included a checklist based on the provisions of the Central Bank of Nigeria (CBN) code and acclaimed national codes and guiding principles to test the level of compliance disclosed by commercial banks in their annual reports.

Main findings: The results show substantial corporate governance disclosures by all the banks except for two corporate governance pillar scores rights and functions of shareholders and engagement with shareholders' associations that received little or no attention in the annual reports of the assessed banks.

Practical/managerial implications: Disclosures do not necessarily imply that preparers comply with the spirit of corporate governance. A governance code that is based on ethics as a foundation should be considered rather than the current comply or else regime.

Contribution/value-add: The article identifies the gap that the comply or else regimes do not necessarily succeed as preparers of report tend to tick the box to comply with the regulation rather than buying into the spirit of that regulation.

Keywords: annual reports; content analysis; corporate governance; Nigerian banks; CBN.

\section{Introduction}

Disclosure and transparency are major features of a good corporate governance framework (Ho \& Wong 2001). Mallin (2002) argues that disclosure plays an important role in preserving the financial system stability of an economy, as well as in boosting investors' confidence in the financial markets. The value of the firm is impacted by its corporate governance practices and by the extension of its disclosure policy. The need for an effective institutional mechanism to supervise and monitor managers to reduce the level of asymmetric information as well as to enhance a corporation's image and reputation to the public cannot be overemphasised (Akhtaruddin et al. 2009). Jensen and Meckling (1976) further observed that there was an inverse relationship between lower transparency and the value of the firm. The need to avail all stakeholders with basic information about the corporation to assist them to make informed judgement on the firm's operations, setting benchmarks for directors to evaluate the appropriateness of their corporate governance practices and inter-company comparison of practices, it is argued, is justification for disclosure rules for corporate governance practices (Ramsay \& Hoad 1997).

Section 342 of Companies and Allied Matters Act (CAMA) C20 Laws of the Federation of Nigeria (LFN) 2004 requires the board of directors to annually prepare a report containing, amongst other information, a fair view of the development of the business of the company and its subsidiaries during the year and of their position at the end of period. Section 34.1 of the Securities and Exchange Commission (SEC) code provides that, to foster good corporate governance, companies should disclose information beyond the requirements of CAMA, whilst section 34.4 of the SEC 
code states that the board of directors shall include, in the annual report, a corporate governance update that conveys to stakeholders the governance structure, policies and practices of the company. In addition, section 34.13 requires the board to use its best judgement to disclose any matter, even though not specifically required to be disclosed in the code if, in the opinion of the board, such matters can significantly affect the financial position of the company or the going concern status of the company (SEC 2011). Similarly, section 5.1.1 of the Central Bank of Nigeria (CBN) code requires banks to make disclosures beyond the statutory and regulatory requirements to enhance good corporate governance (CBN 2014). The foregoing has made disclosure and transparency major features of most corporate governance frameworks as it argues that agency conflicts could be mitigated by disclosure (Ho \& Wong 2001; Jensen \& Meckling 1976).

Disclosures of corporate governance practices in the annual reports are a subtle indication of the level of compliance with provisions of relevant laws and codes. This argument is supported by Akhtaruddin et al. (2009) who submit that higher level disclosures may not necessarily translate to higher transparency. Consequently, this article examines corporate governance practices disclosed in the annual reports of Nigerian banks, taking cognisance of the provisions of laws and codes applicable to Nigerian banks, as well as acclaimed national codes and international guiding principles on corporate governance. It is imperative to state that the code of corporate governance applicable to Nigerian banks ( $\mathrm{CBN}$ code) is very comprehensive as it adopts principles from prominent national codes, such as the UK national code, and guiding principles issued by the Organisation for Economic Co-operation and Development (OECD) as well as Basel Committee on Banking Supervision (BCBS). The objective was to determine the extent of compliance by Nigerian banks as a previous study has shown that disclosures by corporation in developing countries are generally low (Tsamenyi, Enninful-Adu \& Onumah 2007). The article contributes to the literature on disclosure of corporate governance practices in the banking sector of an emerging economy.

The rest of the article is structured as follows: 'Review of related literature: Corporate governance and Nigerian banks' section reviews the literature on corporate governance and Nigeria's banking sector. 'Methodology and approach' section discusses the methodology and the content analysis procedure followed in this article, whilst 'Guidelines for assessing corporate governance disclosure in annual reports of Nigerian banks' section discusses corporate governance and regulatory requirements for Nigerian banks and outlines the specific disclosure requirements in the CBN code. Annual reports of banks' content analysed in this article are presented in 'Corporate governance disclosures and regulatory requirements for Nigerian banks' section, whilst the findings of content analysis on banks' annual reports are presented in 'Annual reports of banks reviewed in this study' section. 'Compliance with statutory and regulatory requirements by Nigerian banks' section concludes the article.

\section{Review of related literature: Corporate governance and Nigerian banks}

Corporate governance involves managing relationships of corporation and its stakeholders (OECD 1999, 2004). The global interest in corporate governance has been attributed to increasing integration of national financial markets resulting from the flow of Foreign Direct Investment that arises from the impact of improvement in information and communication technology on cross-border trade and business activities, as well as recent collapse of world-class corporations, such as Enron, Pamalat and Baring Bank (Okeahalam \& Akinboade 2003; Solomon 2007; Yoshikawa $\&$ Rasheed 2009). To address the corporate governance challenges in Nigeria, various codes of corporate governance, including industry-specific codes and codes that are applicable to all companies listed on the Nigerian Stock Exchange (NSE), have been developed over the years (Osemeke \& Adegbite 2016). The SEC first issued its code in 2003 and revised it in 2011. The SEC code is applicable to all companies listed on the NSE, as well as to companies seeking to raise funds from the capital market through the issuance of securities, or those seeking listing by introduction and all other public companies. In 2007, the SEC further issued a code to guide the conduct of Shareholders' Associations (SEC code for Shareholders). The SEC code for shareholders is to regulate the conduct of members of Shareholders Associations during general meetings of public companies, as well as their relationship with public companies outside general meetings and other relevant matters.

On its part, Nigeria's Bankers' Committee issued a code of corporate governance for banks and other financial institutions in 2003. This code is applicable to the banking sector as it applies to all banks, including those not listed on the NSE. In 2006, the CBN issued its code of corporate governance ( $\mathrm{CBN}$ code), which was revised in 2014. Complying with the provisions of the CBN code is compulsory for all deposit money banks and discount houses operating in Nigeria. The Pension Commission of Nigeria's Code of Corporate Governance for Licensed Pension Operators (Pension Code) was issued in 2008. The Pension code is mandatory for all Pension Fund Administrators (PFAs), including Closed Pension Fund Administrators (CPFAs) and Pension Fund Custodians (PFCs). Furthermore, in 2009, the National Insurance Commission (NAICOM) code of good corporate governance for insurance industry (NAICOM code) was issued. The NAICOM code applies to all insurance and reinsurance companies where it is the primary regulator. 
A cursory look at the trend of events in the Nigerian banking sector in the last two decades shows that the inefficiency and indeed the failure of some banks are attributed to inadequate capital base, ineffective risk management and poor corporate governance practices (Moloi 2016a, 2016b; Soludo 2004). A mandatory code of corporate governance was introduced after the consolidation of Nigeria's 89 banks to 24 banks. The code became effective on 02 April 2006 to provide guidance on the best practices to the banking sector (CBN code 2006). Just 3 years after the CBN code was introduced, the CBN governor fired the chief executive and executive members of the board of directors of eight banks (eight banks is equivalent to one-third of the licensed banks in Nigeria), citing weak corporate governance and risk management practices (Sanusi 2010). As the CBN governor acted, he lamented the fact that consolidation had created bigger banks but failed to overcome the fundamental weaknesses in corporate governance, leading to many Nigerian banks becoming engaged in unethical and potentially fraudulent business practices. The breaches discovered included, among others, the following:

- Manipulation of stock price by chief executive officers (CEOs),

- Purchase of estates all over the world by directors through special purpose vehicles (SPVs) established to lend money to themselves,

- Board members obtaining unsecured loans to the detriment of depositors,

- Inability of the board to check the excesses of executive management, and

- Ineffective boards characterised by dominating chairmen or CEOs, directors lacking the required qualifications and independence (Sanusi 2010).

The flagrant breaches of good corporate governance prompted a review of the 2006 CBN code and the 2003 SEC code. The SEC issued a revised code of corporate governance in 2011 (SEC 2011). The prudential guideline for banks that has been in operation since 1990 was revised with effect from 01 July 2010 (CBN 2010). The CBN in a circular dated 16 May 2014 informed the Nigerian public that it had revised the 2006 CBN code now applicable to banks and discount houses (CBN 2014). The circular stated amongst other things that '... the revised Code of Corporate Governance aims to align the code with current realities and global best practices' (CBN 2014:1).

\section{The circular went further to state that:}

To monitor its full implementation, banks and discount houses are required to submit quarterly returns on their compliance with provisions of the Code. The returns should reach Director, Financial Policy and Regulation Department not later than 7 days after the end of each quarter. (CBN 2014:1)

Following the revision of the 2006 code, which was repealed by the 2014 code in July 2016, the CBN announced the dismissal of the management and board of Skye Bank Plc (a deposit money bank) on issues that were said to be bordering on corporate governance matters (Punch 2016:13). This raises concern as to the efficacy of the CBN 2014 code in totally tackling corporate governance problems in Nigerian banks. Whilst sceptics of the CBN code might attribute the breaches in governance at Skye Bank Plc to inadequacies in the extant CBN code, there is a need to exercise caution in reaching such a conclusion. The ingenious attitudes of some individuals at circumventing rules and procedures, especially in a country with weak institutional settings (Adegbite 2015), cannot be overruled. This view is supported by Ahunwan (2002) who opines that Nigeria's problems (including corporate governance) could be attributed to unethical behaviour of individuals, as well as the unwieldiness of its political and economic system.

Liberalisation of the Nigerian economy spurred an increase in the application and approval of new banking licences as there were 121 banks in 1994 compared with 38 banks in 1984, even though most of the licenses issued during the period were alleged to be issued to retired military officers and their cronies who also undermined the requirements for a banking licence (Olaniyan 2005). The impact of the astronomical increase in the number of licensed banks on the social and economic life of Nigerians is, however, debatable. The paradox of the Nigerian banking sector is such that its performance indicators are often at variance with that of the real sector, suggesting a disconnection between banks' objectives and overall interest of the society. For instance, according to Sanusi (2010) in the period between 2000 and 2007, whilst Nigerian banks were reporting super profits with major positive impact on the Gross Domestic Product (GDP), on the other hand, the level of unemployment and poverty worsened as factories were closing down and workers were being laid off. This is an indicator that Nigerian banks, just like their counterparts in the United States and the United Kingdom, are directed and controlled based on the agency theory perspective, which sees businesses as focussing on maximisation of shareholders' wealth, rather than the stakeholder theory, which sees businesses as considering the interests of all stakeholders by being accountable to shareholders and being responsible to other stakeholders.

Bank failure appears to be a reoccurring decimal in the annals of banking in Nigeria. For instance, Egbo (2012) reports that 21 of the 25 indigenous banks established in 1954 failed because of problems such as inadequate capital, mismanagement, overtrading, lack of regulation and unfair competition from the foreign-owned banks. Concerned about the distressed state of some banks, the CBN issued the prudential guidelines in 1990, whilst the military government promulgated the Banks and Other Financial Institutions Decree (BOFID) in 1991 to strengthen regulation of the banking and financial institutions sector.

Despite these measures, between 1994 and 1998, the licences of 31 banks were revoked and transferred to NDIC for liquidation (CBN Bank Supervision Report 1998). In January 
2006, licences of a further 14 banks were also revoked (CBN Bank Supervision Report 2006) bringing the number of banks that failed in a period of about 12 years to 45 . Furthermore, the licences of three of the banks rescued in 2009 (Spring Bank Plc, Bank PHB Plc and Afribank Nigeria Plc) were eventually revoked by the CBN as they were unable to meet the September 2011 stipulated deadline for recapitalisation (CBN 2011).

It may be argued that at the root of the banks' distress is poor corporate governance culture. This point is premised on the reasons often adduced for the failure of the banks, which include capital inadequacy, mismanagement and poor risk management, amongst others. Corporate governance, as it has been argued, involves establishment of principles, processes and procedures for efficient and effective running of corporations, including banks (Solomon 2007).

Banks are expected to comply with rules and standards on capital adequacy, management, equity and liquidity to guarantee their survival and growth, as well as to fulfil their core mandate of meeting the expectations of shareholders and other stakeholders. Regulators are also expected to ensure compliance with established rules and procedures. It would, thus, appear as if some of these banks were failed banks at inception because of the failure of regulation, an important corporate governance mechanism in an emerging economy like Nigeria's because, as Olaniyan (2005) points out, some of these banks did not fulfil all the requirements that could ensure the commencement of a stable and efficient bank before they were issued banking licences.

The willingness of any corporation to embrace the spirit of any rules or standards rather than act in breach of such rules depends, to a large extent, on the governance culture of the corporation that promotes probity, transparency and accountability. This view is also shared by the CBN (2006), as it reports that poor corporate governance was one of the major factors that were prevalent amongst distressed financial institutions in Nigeria as an abysmal figure of about $40 \%$ of companies, including banks, listed on the NSE had formalised code of corporate governance. This may have prompted the mandatory code of corporate governance issued in 2006 by the CBN to address breaches that border on corporate governance.

The CBN has reported several times (CBN 2008, 2013, 2015) that as the code of corporate governance post-consolidation in 2006 became effective, good corporate governance practices have improved significantly amongst Nigerian banks. The CBN referred to a survey conducted by the International Finance Corporation in 2007, which indicated, amongst other things, that the Nigerian banking sector had embarked on a couple of corporate governance initiatives that had improved transparency and information disclosure as Nigerian banks now maintained proper board structure and processes, which included board committees, ensuring board members possess relevant qualifications, as well as procedures for evaluating board performance amongst other achievements.

The CBN, however, expressed concern about the actual implementation of the provisions of the code on appointment and shareholding status of independent directors, qualifications of Head of Internal Audit and signatories to statutory returns. Therefore, the CBN adopted on-site and off-site procedures to address these challenges. On-site verification reveals non-compliance with provision of the code on succession plan, whistle-blowing, establishment of board audit committee, reporting of interests of internal and external auditors as well as the remuneration of executive and non-executive directors, external auditor's report on risk management, tenure of directors and board appraisal. The CBN also reported in its 2007 report that it was considering a review of the code issued in 2006 to accommodate concerns expressed and challenges encountered with regard to compliance by the banks (CBN 2008).

It may be argued that the delay in carrying out the necessary amendments to the code issued by the CBN in 2006 based on the concerns expressed and the result of the on- and off-site procedures on implementation of the code by the banks is partly responsible for the distressed position of eight banks and the release of bailout fund to salvage the banks in 2009, despite the purported minimum capitalisation of 25 billion naira (N25b) of all licensed banks in January 2005. It will be recalled that the CEOs and executive members of board of directors of eight deposit money banks were sacked by the CBN on matters relating to corporate governance breaches (Sanusi 2010). The CBN eventually amended its 2006 code in 2014 alongside issuing guidelines for discount houses and whistle-blowing in the Nigerian banking sector to eliminate the challenges identified that made some aspects of the 2006 code difficult to implement. Despite the new CBN code 2014, the chairman, $\mathrm{CEO}$, two longest serving directors and all non-executive directors of Skye Bank Plc, a deposit money bank, were replaced by the CBN because the bank could not meet the regulator's minimum key liquidity and capital adequacy ratio (Punch 2016).

The importance of disclosure and transparency to corporations cannot be overemphasised as the information gap could create crisis for the corporation, as well as unhealthy rivalry between the corporation and its stakeholders. Disclosure and transparency are critical to successful stakeholder management. The attraction of investors, as well as other stakeholders' perception of a corporation, is largely dependent on the information available to them about the corporation's operations and governance. Consequently, the fifth OECD principle of corporate governance provides that:

The corporate governance framework should ensure that timely and accurate disclosure is made on all material matters regarding the corporation, including the financial situation, performance, ownership, and governance of the company. (OECD 2015:37) 
Corporations should disclose information about their financial and operating activities. The principle further recommends that information disclosure should not be restricted to financial information but should include information on corporation objectives, ownership, voting rights, key executives, board of directors and their remuneration. Information on related party transactions, foreseeable risk factors, governance structures and policies, as well as issues concerning employees and other stakeholders, should be disclosed. The disclosure of the information should conform to recognised standards. Furthermore, to assure stakeholders of the veracity of information disclosed, an independent and competent person or body expected to exercise due care and diligence is required to conduct an annual audit and present a report to shareholders (OECD 2015). Similarly, the Commonwealth Association for Corporate Governance (CACG) sixth principle requires boards of directors to ensure that there is effective communication between all its stakeholders (CACG 1999), whilst the fifth principle of King IV code requires the governing body to ensure that reports issued by the organisation enable stakeholders to make informed assessments of the organisation's performance and its short-, medium- and long-term prospects (IoD 2016). The BCBS' 12th principle on its part expects banks to show enough transparency in its dealings with shareholders, depositors and other relevant stakeholders, including market participants (BIS 2015). As stated earlier, the objective of this article was to assess corporate governance disclosures by Nigerian banks. 'Methodology and approach' section discusses the methodology used to assess corporate disclosures by Nigerian banks.

\section{Methodology and approach}

We used content analysis methodology to assess corporate governance disclosures by Nigerian banks. Content analysis is a data collection method that systematically draws valid and replicable inferences from documents, with the purpose of providing a condensed and broad description of a phenomenon (Drisko \& Maschi 2016; Krippendorff 1980; Stemler 2001). It entails word counts and the use of other quantitative analytical methods to analyse data in addition to verifying the reliability and validity of the coding processes of texts being analysed. It uses a set of procedures to make valid inferences from texts about the message, the sender and the targeted audience (Weber 1990). The aim is to gain a concise and broad insight about a phenomenon being investigated by 'distilling words into fewer content related categories' (Elo \& Kyngäs 2008).

Although there are variants of content analysis, these are basically qualitative or quantitative in their approach. The choice of approach depends on the research questions and research objectives. Qualitative content analysis begins with identifying themes that can bring out the desired statements or sentences from texts that subsequently provide basis upon which thematic patterns are established that may result in quantitative content analysis (Neuendorf 2017). Qualitative content analysis further enables the researcher to focus on the narrative description of the meaning of communication in specific contexts instead of the statistical analysis of word counts (Drisko \& Maschi 2016).

Specifically, we used qualitative content analysis that included a checklist (Moloi 2008) based on the provisions of the CBN code and acclaimed national codes and guiding principles to test the level of compliance disclosed by commercial banks in their annual reports. A copy of the checklist appears in Appendix 1. As it is indicated in the introduction of this article, disclosure is a subtle indication of the level of compliance; therefore, disclosures in annual reports will assist in determining the extent of compliance with rules, laws and codes.

The procedure followed to test the level of compliance disclosed in the annual reports of banks is outlined below:

- Step 1 - Source for the list of licensed deposit money banks in Nigeria (Appendix 4 - list of banks).

- Step 2 - Categorise banks according to geographical authorisation and scope of operation.

- Step 3 - Download annual reports of commercial banks.

- Step 4-Review the relevant sections of the annual reports by using the checklist in Appendix 1.

- Step 5 - Perform content analysis on each annual report to test compliance with disclosure requirements.

- Step 6-Record data in a spreadsheet (Appendix 3).

- Step 7 - Analyse data

- Step 8 - Present results in 'Corporate governance disclosures and regulatory requirements for Nigerian banks' section.

To analyse compliance disclosed in the annual report, the coding principles were formulated based on sections of the CBN code, acclaimed national codes and international guiding principles (Appendix 2). Thereafter, the annual reports were analysed by finding keywords that indicate that the corporate governance practices are disclosed in the annual reports. The result of these initial findings was entered into a spreadsheet for further analysis.

Section 2.8.3 of the CBN code requires banks to engage consultants to carry out an evaluation of the performance of board of directors, which often entails a review of the bank's corporate and statutory documents, minutes of board and committee meetings, policies and procedures, interaction with directors and key management staff to ascertain the level of board compliance with the provision of the CBN code, statutory requirements, as well as global best practice. The report of these consultants gives an indication of the level of compliance. Consequently, in addition to checklist, this study also assesses the opinion of the consultants engaged to appraise the board, as well as to evaluate corporate governance practices of the banks disclosed in the annual reports. 


\section{Guidelines for assessing corporate governance disclosure in annual reports of Nigerian banks}

To assess the banks' corporate governance disclosure in the annual report, the guidelines fully disclosed, partly disclosed or not disclosed on Table 1 are used. The information collected from the annual reports was disclosed in the spreadsheet to gain insight into corporate governance practices of the banks.

\section{Corporate governance disclosures and regulatory requirements for Nigerian banks}

Banks are substantially regulated to safeguard depositors' investments (Moloi 2014). In addition, the code of corporate governance for Nigerian banks is mandatory (CBN 2014). Disclosure and transparency are major components of a good corporate governance framework as earlier noted. Consequently, periodic reports like monthly, quarterly and annual reports, as well as adhoc reports, are often prepared by the corporation to disseminate information to its stakeholders. Apart from disclosure requirements in CAMA LFN 2004 and the SEC code, the focus of section 5.0 of the CBN code applicable to all banks and discount houses in Nigeria is disclosure and transparency. The CBN code requires banks to have a website, which shall host information on major developments in the banks, risk management practices and executive compensation amongst others, as well as serve as a channel of communication with shareholders (Section 3.1.3). One of the documents expected to be found on the bank website is the annual reports of the banks. This article, therefore, uses the annual reports of banks hosted on the banks' website to investigate the disclosure of corporate governance practices amongst Nigerian banks (CBN 2014).

The CBN code in the sections of the code outlined below specifically requires banks to make certain disclosures in their annual reports to enhance transparency in the conduct of the affairs of the banks:

- General disclosure: Section 5.1.1 encourages banks to make disclosures beyond statutory requirements of the Banking and Other Financial Institutions Act (BOFIA) 2004

TABLE 1: Content analysis guidelines.

\begin{tabular}{|c|c|c|c|}
\hline Variable & Fully disclosed & Not disclosed & Partly disclosed \\
\hline Guidelines & $\begin{array}{l}\text { If the required } \\
\text { information according to } \\
\text { Appendix } 1 \text { is disclosed } \\
\text { under its category in a } \\
\text { paragraph, a few } \\
\text { paragraphs or a full page } \\
\text { and this information } \\
\text { contains all the required } \\
\text { information, as well as } \\
\text { voluntary disclosures for } \\
\text { that category, the item } \\
\text { isticked as 'Yes' in the } \\
\text { checklist. }\end{array}$ & $\begin{array}{l}\text { If there is no } \\
\text { disclosure at all } \\
\text { of the minimum } \\
\text { required } \\
\text { information } \\
\text { according to } \\
\text { Appendix 1, the } \\
\text { item is ticked as } \\
\text { 'No' in the } \\
\text { checklist. }\end{array}$ & $\begin{array}{l}\text { If the minimum required } \\
\text { information is disclosed } \\
\text { according to Appendix } 1 \text {, } \\
\text { but this information is } \\
\text { not disclosed separately } \\
\text { under its category, and is } \\
\text { not disclosed in detail, } \\
\text { that is, appears in one } \\
\text { sentence that does not } \\
\text { give adequate details, the } \\
\text { item isticked partly in the } \\
\text { checklist. }\end{array}$ \\
\hline
\end{tabular}

Source: Adapted from Moloi, S.T.M., 2008, 'Assessment of corporate governance reporting in the annual reports of South African listed companies', Masters dissertation, University of South Africa. and Companies and Allied Matters Act (CAMA) C20 LFN, 2004 to enhance good corporate governance.

- Board meetings: Section 2.6.3 of the CBN code states that the board in the corporate governance section of the annual report discloses the total number of board meetings held in the financial year, as well as attendance by each director.

- Remuneration policy: Section 2.7.4 requires banks to have a remuneration policy put in place by the board of directors, which shall be disclosed to shareholders in the annual report.

- Directors' shareholding and related parties: - Section 2.7.11 states that banks shall disclose the details of the shares held by directors and their related parties in their annual reports.

- Board appraisal: Section 2.8.3 requires banks to present, to shareholders at the Annual General Meeting (AGM), board appraisals conducted by an independent auditor.

- Section 5.1.2 states that banks shall disclose, in their annual report, all information, including:

- Major items that have been estimated in accordance with applicable accounting and auditing standards.

- Rationale for material estimates.

- Information on directors' transactions and other related activities with the bank.

- Corporate governance;

- Risk assets;

- Risk management;

- Information on strategic modification to the core business;

- All regulatory and supervisory contraventions during the year under review and infractions uncovered through whistle-blowing, including actions taken thereon;

- Regulatory sanctions and penalties;

- Capital structure and adequacy;

- Any service contracts and other contractual relationships with related parties;

- Frauds and forgeries;

- Contingency planning framework;

- Any matter not specifically mentioned in the code but which is capable of affecting in significant form the financial condition of the bank or its status as a going concern.

- Section 7.1.4 also requires banks to disclose at least a summary of their policy on trading in the securities of the bank by directors, management and staff of the bank (CBN 2014).

It should be noted that these requirements are consistent with acclaimed national codes and international guiding principles.

\section{Annual reports of banks reviewed in this study}

The extant CBN code became effective on 01 October 2014. The financial year of banks in Nigeria mandatorily starts on 01 January and ends on 31 December. This article reviewed 
annual reports for the years ending 31 December 2014, 2015, 2016 and 2017. The reason for choosing the year ending 31 December 2014 as the start date for the content analysis of the annual report is to determine the trend of compliance with the code from the date it became effective, notwithstanding the fact that it was 3 months to the end of the financial year of the banks.

The following banks' annual reports for 2014, 2015, 2016 and 2017 were downloaded from the banks' websites: Access Bank Plc, Citi Bank Nigeria Limited, Diamond Bank Plc, Ecobank Plc and First Bank Plc. Others include FCMB Plc, Fidelity Bank Plc, GT Bank Plc, Stanbic IBTC Plc, Sterling Bank Plc, Suntrust Bank Nigeria Limited, UBA Plc, Union Bank Plc, Unity Bank Plc and Wema Bank Plc. Table 2 shows banks, type of authorisation and year of annual reports analysed in this article.

The next section discusses corporate governance information disclosed in the annual reports of Nigerian banks based on the requirements of acclaimed corporate governance codes and guiding principles.

\section{Compliance with statutory and regulatory requirements by Nigerian banks}

Studies have shown that the level of disclosure in developing countries is significantly affected by ownership structure, distribution of shareholding and size of the corporation, whilst there is an insignificant correlation between disclosure and leverage (Tsamenyi et al. 2007). This article, as earlier indicated, cautiously aligns with the view that disclosure in annual reports is evidence of compliance. However, to further assure readers of the veracity of the information disclosed in the annual reports, officers of the company and independent persons often not connected to the company are required to make a declaration that the information contained in the annual report represents a fair

TABLE 2: Name of banks, type of authorisation and years of annual reports.

\begin{tabular}{lllcccc}
\hline No. & Name of banks & $\begin{array}{l}\text { Type of } \\
\text { authorisation }\end{array}$ & \multicolumn{5}{c}{ Annual reports } \\
\cline { 3 - 6 } & & 2014 & 2015 & 2016 & 2017 \\
\hline 1. & Access Bank Plc & International & N/A & A & A & A \\
2. & Citi Bank Nigeria Ltd & National & N/A & A & A & A \\
3. & Diamond Bank Plc & International & A & N/A & A & A \\
4. & Ecobank Plc & National & A & A & A & A \\
5. & First Bank Nigeria Plc & International & A & A & A & A \\
6. & FCMB Plc & International & A & A & A & A \\
7. & Fidelity Bank Plc & International & A & A & A & A \\
8. & GT Bank Plc & International & A & N/A & A & A \\
9. & Stanbic IBTC Plc & National & A & A & A & A \\
10. & Sterling Bank Plc & National & N/A & A & A & A \\
\hline 11. & SunTrust Bank Ltd & Regional & N/A & N/A & A & N/A \\
12. & UBA Plc & International & A & A & A & A \\
13. & Union Bank Plc & International & A & A & A & A \\
14. & Unity Bank Plc & National & A & A & A & N/A \\
15. & Wema Bank Plc & National & N/A & A & A & A \\
\hline A
\end{tabular}

A, available; N/A, not available. view of the financial, operating activities and other relevant information of the company in the period under review. Both the SEC and CBN codes require the board to engage an independent consultant to evaluate the corporate governance status of the bank and the report be disclosed in the annual report.

\section{Findings relating to content analyses of selected annual reports of Nigerian banks}

This section discusses the findings on disclosure of corporate governance practices in the annual reports of Nigerian banks.

\section{Ethical consideration}

Ethical approval was received from the University of Johannesburg, reference number: SAREC20180514-02.

\section{Results of content analysis of annual reports}

Data indicate that in 2014, only 12 banks' annual reports were available out of 15 banks assessed in the study. Despite the fact that the CBN code became effective 3 months to the end of the banks' financial year, there was substantial compliance with the provisions of the CBN code, as shown in Table 3. However, two corporate governance pillar scores rights and functions of shareholders and engagement with shareholders associations received little or no attention in the annual reports of the assessed banks. Whilst six (50\%) of the assessed banks' annual reports fully discussed the rights and functions of shareholders, only two (16.7\%) reports disclosed their engagement with shareholders' associations in their annual reports (Table 3).

Awareness of their rights and functions by banks' shareholders, especially in an emerging economy like Nigeria, could enhance good corporate governance practices because the exercise of their rights and performance of their functions by shareholders also serve as checks and balances on board and management. Shareholders' associations, though, as umbrella bodies for all shareholders could be an avenue for minority shareholders to engage board and management of banks on matters of concern, especially when share ownership is dispersed, and in circumstances that may appear like oppression of minority shareholders by majority shareholders.

Furthermore, in 2015, annual reports of 12 banks were assessed. The results of content analysis also show that there was substantial compliance with the provisions of the CBN code by the banks. There was improvement in the number of banks that discussed the rights and functions of shareholders in their annual reports as nine banks (75\%) out of the assessed banks complied with this provision of the CBN code. Engagement with shareholders' associations 
TABLE 3: Content analysis: 2014 annual reports of Nigerian banks.

\begin{tabular}{|c|c|c|c|c|c|c|c|c|c|}
\hline S. No. & $\begin{array}{l}\text { Categories of corporate governance } \\
\text { practices mandated by the CBN code }\end{array}$ & $\begin{array}{c}\text { Full } \\
\text { disclosure }\end{array}$ & $\begin{array}{c}\text { No } \\
\text { disclosure }\end{array}$ & $\begin{array}{l}\text { Partly } \\
\text { disclosed }\end{array}$ & $\begin{array}{c}\text { Not } \\
\text { available }\end{array}$ & $\begin{array}{c}\text { Yes as a \% of } \\
\text { assessed annual } \\
\text { reports }\end{array}$ & $\begin{array}{l}\text { No as a } \% \text { of } \\
\text { assessed annual } \\
\text { reports }\end{array}$ & $\begin{array}{l}\text { Partly as a \% of } \\
\text { assessed annual } \\
\text { reports }\end{array}$ & Total \% \\
\hline 1 & Board and management & 12 & 0 & 0 & 3 & 100.0 & 0.0 & 0.0 & 100.0 \\
\hline 1.1 & Strategic goals & 9 & 1 & 2 & 3 & 75.0 & 8.3 & 16.7 & 100.0 \\
\hline 1.2 & Skills, knowledge and experience & 11 & 1 & 0 & 3 & 91.7 & 8.3 & 0.0 & 100.0 \\
\hline 1.3 & Limit of authority & 11 & 1 & 0 & 3 & 91.7 & 8.3 & 0.0 & 100.0 \\
\hline 1.4 & Ethical conduct & 8 & 3 & 1 & 3 & 66.7 & 25.0 & 8.3 & 100.0 \\
\hline 2 & Size and composition of board & 12 & 0 & 0 & 3 & 100.0 & 0.0 & 0.0 & 100.0 \\
\hline 2.1 & Executive & 12 & 0 & 0 & 3 & 100.0 & 0.0 & 0.0 & 100.0 \\
\hline 2.2 & Non-executive & 12 & 0 & 0 & 3 & 100.0 & 0.0 & 0.0 & 100.0 \\
\hline 3 & Separation of power & 12 & 0 & 0 & 3 & 100.0 & 0.0 & 0.0 & 100.0 \\
\hline 4 & Appointment and tenure of board members & 8 & 3 & 1 & 3 & 66.7 & 25.0 & 8.3 & 100.0 \\
\hline 5 & Board committees & 12 & 0 & 0 & 3 & 100.0 & 0.0 & 0.0 & 100.0 \\
\hline 6 & Board meetings & 12 & 0 & 0 & 3 & 100.0 & 0.0 & 0.0 & 100.0 \\
\hline 7 & Remuneration & 8 & 4 & 0 & 3 & 66.7 & 33.3 & 0.0 & 100.0 \\
\hline 7.1 & Fees & 12 & 0 & 0 & 3 & 100.0 & 0.0 & 0.0 & 100.0 \\
\hline 7.2 & Other emoluments & 12 & 0 & 0 & 3 & 100.0 & 0.0 & 0.0 & 100.0 \\
\hline 8 & Board appraisal & 9 & 2 & 1 & 3 & 75.0 & 16.7 & 8.3 & 100.0 \\
\hline 9 & Rights and functions of shareholders & 6 & 4 & 2 & 3 & 50.0 & 33.3 & 16.7 & 100.0 \\
\hline 10 & Equity ownership & 12 & 0 & 0 & 3 & 100.0 & 0.0 & 0.0 & 100.0 \\
\hline 11 & Protection of shareholders' rights & 8 & 2 & 2 & 3 & 66.6 & 16.7 & 16.7 & 100.0 \\
\hline 12 & General meeting & 12 & 0 & 0 & 3 & 100.0 & 0.0 & 0.0 & 100.0 \\
\hline 13 & Shareholders' association & 2 & 10 & 0 & 3 & 16.7 & 83.3 & 0.0 & 100.0 \\
\hline 14 & Rights of other stakeholders & 9 & 3 & 0 & 3 & 75.0 & 25.0 & 0.0 & 100.0 \\
\hline 15 & Disclosure and transparency & & & & & & & & \\
\hline 15.1 & Accounting estimates & 12 & 0 & 0 & 3 & 100.0 & 0.0 & 0.0 & 100.0 \\
\hline 15.2 & Governance structure & 12 & 0 & 0 & 3 & 100.0 & 0.0 & 0.0 & 100.0 \\
\hline 15.3 & Risk assets & 11 & 1 & 0 & 3 & 91.7 & 8.3 & 0.0 & 100.0 \\
\hline 15.4 & Regulatory contraventions & 10 & 2 & 0 & 3 & 83.3 & 16.7 & 0.0 & 100.0 \\
\hline 15.5 & Sanctions and penalties & 10 & 2 & 0 & 3 & 83.3 & 16.7 & 0.0 & 100.0 \\
\hline 16 & Transparency and integrity reporting & & & & & & & & \\
\hline 16.1 & Audit committee & 12 & 0 & 0 & 3 & 100.0 & 0.0 & 0.0 & 100.0 \\
\hline 16.2 & External auditors & 12 & 0 & 0 & 3 & 100.0 & 0.0 & 0.0 & 100.0 \\
\hline 16.3 & Chief Compliance Officer & 10 & 2 & 0 & 3 & 83.3 & 16.7 & 0.0 & 100.0 \\
\hline 17 & Whistle-blowing & 10 & 2 & 0 & 3 & 83.3 & 16.7 & 0.0 & 100.0 \\
\hline 18 & Risk management & 11 & 1 & 0 & 3 & 91.7 & 8.3 & 0.0 & 100.0 \\
\hline
\end{tabular}

continued to receive little attention in the annual reports of the banks, as only two banks (16.7\%) and four banks (33.3\%) fully and partly discussed their interaction with shareholders' associations in their annual reports, respectively (Table 4).

In 2016, 15 banks' annual reports were assessed. There was substantial compliance by the banks. However, compliance with disclosure of rights and functions of shareholders and engagement with shareholders' associations in the annual reports scored the highest non-compliance as 6 banks (40\%) and 10 banks $(66.7 \%)$ of assessed banks respectively did not disclose them in their annual reports (Table 5).

In 2017, 13 banks were assessed. The results show that the banks made substantial disclosure of their corporate governance practices in their annual reports, except for engagement with shareholders' associations. Only three banks $(23.1 \%)$ disclosed engagement with shareholders' associations in their annual reports (Table 6).

The banks, apart from substantially complying with the disclosure provisions of the CBN and SEC codes in the annual reports, dedicated ample pages to explaining the significance of good governance to banks' growth, sustainability, as well as earning the trust of stakeholders. The structures and procedures that have been established to ensure sound corporate governance in the banks, board charters and the board of directors' commitment to good corporate governance were also reported. For example, the responsibilities of the board of directors and its role as the highest decision-making body for governance, composition of board and board committees were clearly stated in the annual reports.

\section{Findings relating to reports of external consultants}

Section 15.6 of the SEC code provides that the board may engage the services of external consultants to facilitate the performance evaluation of the board, its committees or individual directors. The engagement of the external consultants is to allow for an independent perspective on compliance with the codes, effectiveness of the board and the extent to which the bank has embraced global best practices.

In assessing corporate governance practices disclosures by Nigerian banks, opinions of the external consultants on corporate governance practices of banks were also reviewed. 
TABLE 4: Content analysis: 2015 annual reports of Nigerian banks.

\begin{tabular}{|c|c|c|c|c|c|c|c|c|c|}
\hline S. No. & $\begin{array}{l}\text { Categories of corporate governance } \\
\text { practices mandated by the CBN code }\end{array}$ & $\begin{array}{c}\text { Full } \\
\text { disclosure }\end{array}$ & $\begin{array}{c}\text { No } \\
\text { disclosure }\end{array}$ & $\begin{array}{l}\text { Partly } \\
\text { disclosed }\end{array}$ & $\begin{array}{c}\text { Not } \\
\text { available }\end{array}$ & $\begin{array}{c}\text { Yes as a } \% \text { of } \\
\text { assessed annual } \\
\text { reports }\end{array}$ & $\begin{array}{l}\text { No as a } \% \text { of } \\
\text { assessed annual } \\
\text { reports }\end{array}$ & $\begin{array}{l}\text { Partly as a } \% \text { of } \\
\text { assessed annual } \\
\text { reports }\end{array}$ & Total \% \\
\hline 1 & Board and management & 12 & 0 & 0 & 3 & 100.0 & 0.0 & 0.0 & 100.0 \\
\hline 1.1 & Strategic goals & 12 & 0 & 0 & 3 & 100.0 & 0.0 & 0.0 & 100.0 \\
\hline 1.2 & Skills, knowledge and experience & 10 & 2 & 0 & 3 & 83.3 & 16.7 & 0.0 & 100.0 \\
\hline 1.3 & Limit of authority & 12 & 0 & 0 & 3 & 100.0 & 0.0 & 0.0 & 100.0 \\
\hline 1.4 & Ethical conduct & 7 & 1 & 4 & 3 & 58.3 & 8.3 & 33.3 & 100.0 \\
\hline 2 & Size and composition of board & 12 & 0 & 0 & 3 & 100.0 & 0.0 & 0.0 & 100.0 \\
\hline 2.1 & Executive & 12 & 0 & 0 & 3 & 100.0 & 0.0 & 0.0 & 100.0 \\
\hline 2.2 & Nonexecutive & 12 & 0 & 0 & 3 & 100.0 & 0.0 & 0.0 & 100.0 \\
\hline 3 & Separation of power & 12 & 0 & 0 & 3 & 100.0 & 0.0 & 0.0 & 100.0 \\
\hline 4 & Appointment and tenure of board members & 9 & 1 & 2 & 3 & 75.0 & 8.3 & 16.7 & 100.0 \\
\hline 5 & Board committees & 12 & 0 & 0 & 3 & 100.0 & 0.0 & 0.0 & 100.0 \\
\hline 6 & Board meetings & 12 & 0 & 0 & 3 & 100.0 & 0.0 & 0.0 & 100.0 \\
\hline 7 & Remuneration & 9 & 3 & 0 & 3 & 75.0 & 25.0 & 0.0 & 100.0 \\
\hline 7.1 & Fees & 12 & 0 & 0 & 3 & 100.0 & 0.0 & 0.0 & 100.0 \\
\hline 7.2 & Other emoluments & 11 & 0 & 1 & 3 & 91.7 & 0.0 & 8.3 & 100.0 \\
\hline 8 & Board appraisal & 9 & 1 & 2 & 3 & 75.0 & 8.3 & 16.7 & 100.0 \\
\hline 9 & Rights and functions of shareholders & 9 & 2 & 1 & 3 & 75.0 & 16.7 & 8.3 & 100.0 \\
\hline 10 & Equity ownership & 12 & 0 & 0 & 3 & 100.0 & 0.0 & 0.0 & 100.0 \\
\hline 11 & Protection of shareholders' rights & 9 & 2 & 1 & 3 & 75.0 & 16.7 & 8.3 & 100.0 \\
\hline 12 & General meeting & 12 & 0 & 0 & 3 & 100.0 & 0.0 & 0.0 & 100.0 \\
\hline 13 & Shareholders' association & 2 & 6 & 4 & 3 & 16.7 & 50.0 & 33.3 & 100.0 \\
\hline 14 & Rights of other stakeholders & 10 & 1 & 1 & 3 & 83.3 & 8.3 & 8.3 & 100.0 \\
\hline 15 & Disclosure and transparency & & & & & & & & \\
\hline 15.1 & Accounting estimates & 12 & 0 & 0 & 3 & 100.0 & 0.0 & 0.0 & 100.0 \\
\hline 15.2 & Governance structure & 12 & 0 & 0 & 3 & 100.0 & 0.0 & 0.0 & 100.0 \\
\hline 15.3 & Risk assets & 12 & 0 & 0 & 3 & 100.0 & 0.0 & 0.0 & 100.0 \\
\hline 15.4 & Regulatory contraventions & 10 & 1 & 1 & 3 & 83.3 & 8.3 & 8.3 & 100.0 \\
\hline 15.5 & Sanctions and penalties & 10 & 1 & 1 & 3 & 83.3 & 8.3 & 8.3 & 100.0 \\
\hline 16 & Transparency and integrity reporting & & & & & & & & \\
\hline 16.1 & Audit committee & 12 & 0 & 0 & 3 & 100.0 & 0.0 & 0.0 & 100.0 \\
\hline 16.2 & External auditors & 12 & 0 & 0 & 3 & 100.0 & 0.0 & 0.0 & 100.0 \\
\hline 16.3 & Chief Compliance Officer & 11 & 1 & 0 & 3 & 91.7 & 8.3 & 0.0 & 100.0 \\
\hline 17 & Whistle-blowing & 10 & 2 & 0 & 3 & 83.3 & 16.7 & 0.0 & 100.0 \\
\hline 18 & Risk management & 12 & 0 & 0 & 3 & 100.0 & 0.0 & 0.0 & 100.0 \\
\hline
\end{tabular}

These opinions are attached to annual reports. External consultants have an important role as they assist the CBN with reviews on banks' compliance with corporate governance. In reviewing these opinions, it was evident that external consultants were generally of the view that there was substantial compliance with the provisions of the code.

It was observed that the opinion of the external consultants included statements like:

... the bank complies with relevant provisions of the SEC and the CBN codes of corporate governance, except for the provision ...

The above statement suggests some level of compliance whilst a statement such as the one that follows appears to indicate total compliance:

We affirm that the Board has complied with the provisions of the CBN CODE and other relevant corporate governance best practices.

In 2016 and 2017, the Citi Bank external consultant stated as follows:

On the basis of our work, it is our conclusion that the Board has maintained an enviable standard of compliance with the provisions of the Code as well as the principles, practices and processes of good corporate governance (Citi Bank 2016). (p. 50)

On the basis of our work, the Board of Citibank has largely complied with the requirements of the CBN CCG during the year ended December 31, 2017 (Citi Bank 2017). (p. 56)

In its corporate governance report for 2016, Stanbic Bank Plc (2016) states that:

We confirm that as at the year ended 31 December 2016 the company has complied in all material respects with the principles set out in the CBN's code of corporate governance. (p. 111)

In 2016, the external consultant of Diamond Bank Plc (2016) reported as follows:

The Board of Diamond Bank Plc. achieved significant compliance with the provisions of the Code ... We have also identified areas for improvement during the course of our reviews. The Bank should update its succession plan to reflect the successors for the $\mathrm{CEO}$ and $\mathrm{CFO}$ positions. Details of our other findings are contained in our full report to the Board. (p. 74)

whilst in 2017, it was reported that (Diamond Bank Plc 2017):

The board has complied to a large extent with the directives of the code. (p. 76) 
TABLE 5: Content analysis: 2016 Annual Reports of Nigerian banks.

\begin{tabular}{|c|c|c|c|c|c|c|c|c|c|}
\hline S. No. & $\begin{array}{l}\text { Categories of corporate governance } \\
\text { practices mandated by the CBN code }\end{array}$ & $\begin{array}{c}\text { Full } \\
\text { disclosure }\end{array}$ & $\begin{array}{c}\text { No } \\
\text { disclosure }\end{array}$ & $\begin{array}{c}\text { Partly } \\
\text { disclosed }\end{array}$ & $\begin{array}{c}\text { Not } \\
\text { available }\end{array}$ & $\begin{array}{l}\text { Yes as a } \% \text { of } \\
\text { assessed annual } \\
\text { reports }\end{array}$ & $\begin{array}{l}\text { No as a } \% \text { of } \\
\text { assessed annual } \\
\text { reports }\end{array}$ & $\begin{array}{l}\text { Partly as a \% of } \\
\text { assessed annual } \\
\text { reports }\end{array}$ & Total \% \\
\hline 1 & Board and management & 15 & 0 & 0 & 0 & 100.0 & 0.0 & 0.0 & 100.0 \\
\hline 1.1 & Strategic goals & 12 & 1 & 2 & 0 & 80.0 & 6.7 & 13.3 & 100.0 \\
\hline 1.2 & Skills, knowledge and experience & 13 & 2 & 0 & 0 & 86.7 & 13.3 & 0.0 & 100.0 \\
\hline 1.3 & Limit of authority & 14 & 0 & 1 & 0 & 93.3 & 0.0 & 6.7 & 100.0 \\
\hline 1.4 & Ethical conduct & 9 & 3 & 3 & 0 & 60.0 & 20.0 & 20.0 & 100.0 \\
\hline 2.1 & Executive & 14 & 0 & 1 & 0 & 93.3 & 0.0 & 6.7 & 100.0 \\
\hline 2.2 & Non-Executive & 14 & 0 & 1 & 0 & 93.3 & 0.0 & 6.7 & 100.0 \\
\hline 3 & Separation of power & 14 & 0 & 1 & 0 & 93.3 & 0.0 & 6.7 & 100.0 \\
\hline 4 & Appointment and tenure of board members & 11 & 2 & 2 & 0 & 73.3 & 13.3 & 13.3 & 100.0 \\
\hline 5 & Board committees & 13 & 2 & 0 & 0 & 86.7 & 13.3 & 0.0 & 100.0 \\
\hline 6 & Board meetings & 13 & 2 & 0 & 0 & 86.7 & 13.3 & 0.0 & 100.0 \\
\hline 7 & Remuneration & 14 & 1 & 0 & 0 & 93.3 & 6.7 & 0.0 & 100.0 \\
\hline 7.2 & Other emoluments & 14 & 1 & 0 & 0 & 93.3 & 6.7 & 0.0 & 100.0 \\
\hline 8 & Board appraisal & 10 & 3 & 2 & 0 & 66.7 & 20.0 & 13.3 & 100.0 \\
\hline 9 & Rights and functions of shareholders & 9 & 6 & 0 & 0 & 60.0 & 40.0 & 0.0 & 100.0 \\
\hline 10 & Equity ownership & 15 & 0 & 0 & 0 & 100.0 & 0.0 & 0.0 & 100.0 \\
\hline 11 & Protection of shareholders' rights & 10 & 5 & 0 & 0 & 66.7 & 33.3 & 0.0 & 100.0 \\
\hline 12 & General meeting & 13 & 2 & 0 & 0 & 86.7 & 13.3 & 0.0 & 100.0 \\
\hline 13 & Shareholders' association & 1 & 10 & 4 & 0 & 6.7 & 66.7 & 26.7 & 100.0 \\
\hline 14 & Rights of other stakeholders & 6 & 5 & 4 & 0 & 40.0 & 33.3 & 26.7 & 100.0 \\
\hline 15 & Disclosure and transparency & & & & & & & & \\
\hline 15.1 & Accounting estimates & 15 & 0 & 0 & 0 & 100.0 & 0.0 & 0.0 & 100.0 \\
\hline 15.2 & Governance structure & 14 & 0 & 1 & 0 & 93.3 & 0.0 & 6.7 & 100.0 \\
\hline 15.3 & Risk assets & 13 & 0 & 2 & 0 & 86.7 & 0.0 & 13.3 & 100.0 \\
\hline 15.4 & Regulatory contraventions & 12 & 2 & 1 & 0 & 80.0 & 13.3 & 6.7 & 100.0 \\
\hline 15.5 & Sanctions and penalties & 12 & 2 & 1 & 0 & 80.0 & 13.3 & 6.7 & 100.0 \\
\hline 16.2 & External auditors & 15 & 0 & 0 & 0 & 100.0 & 0.0 & 0.0 & 100.0 \\
\hline 16.3 & Chief Compliance Officer & 13 & 2 & 0 & 0 & 86.7 & 13.3 & 0.0 & 100.0 \\
\hline 17 & Whistle-blowing & 11 & 2 & 2 & 0 & 73.3 & 13.3 & 13.3 & 100.0 \\
\hline 18 & Risk management & 15 & 0 & 0 & 0 & 100.0 & 0.0 & 0.0 & 100.0 \\
\hline
\end{tabular}

The evaluation of First Bank Plc by the consultant in 2014 and 2017 is as follows:

FBN Holdings' corporate governance practices are largely in compliance with the key provisions of the CBN Code and SEC Code. Specific recommendations for further improving FBN Holdings' governance practices have been articulated and included in our detailed report to the Board. (FBN 2014: 192)

... [E]xcept as noted below, the Company's corporate governance practices are largely in compliance with the key provisions of the CBN and SEC Codes. Specific recommendations for further improving the Company's governance practices have been articulated and included in our detailed report to the Board. The key areas identified include enhancement of the Company's related party process. (FBN 2017: 84)

The assessment of GT Bank Plc (2017) is similar to First Bank Plc. It reads:

On the basis of our work, the Board of Guaranty Trust Bank Plc has largely complied with the requirements of Section 2.8.3 of the Central Bank of Nigeria (CBN) Revised Code of Corporate Governance (CCG) 2014 during the year ended December 31, 2017. (p. 70)
In the case of Stanbic IBTC Bank Plc (2017), the opinion of the consultant is as follows:

We confirm that as at the year ended 31 December 2017 the company has complied in all material respects with the principles set out in the CBN's code of corporate governance. (p. 119)

Unity Bank reported, in 2015, that the bank complied fully with Section 5.1.2 of the CBN code. The bank, however, reported that it had established a Compliance Division with responsibilities of implementing and monitoring the CBN code, and that it had paid penalties on violation of two sections of the code as at 31 December 2015.

Whilst most of the banks stated in their reports what suggest some degree of compliance with the CBN code, Sterling Bank $\mathrm{Plc}$ did not report on its evaluation of its corporate governance status by an independent consultant. It, however, reported on its Whistle-Blowing policy in its notes to the financial statements.

The bank stated in both the 2015 and 2016 reports that:

The Bank complied with CBN circular FPR/DIR/CIR/ GEN/01/004, Code of Corporate Governance from Banks and 
TABLE 6: Content analysis: 2017 Annual Reports of Nigerian banks.

\begin{tabular}{|c|c|c|c|c|c|c|c|c|c|}
\hline S. No. & $\begin{array}{l}\text { Categories of corporate governance } \\
\text { practices mandated by the CBN code }\end{array}$ & $\begin{array}{c}\text { Full } \\
\text { disclosure }\end{array}$ & $\begin{array}{c}\text { No } \\
\text { disclosure }\end{array}$ & $\begin{array}{l}\text { Partly } \\
\text { disclosed }\end{array}$ & $\begin{array}{c}\text { Not } \\
\text { available }\end{array}$ & $\begin{array}{c}\text { Yes as a } \% \text { of } \\
\text { assessed annual } \\
\text { reports }\end{array}$ & $\begin{array}{l}\text { No as a } \% \text { of } \\
\text { assessed annual } \\
\text { reports }\end{array}$ & $\begin{array}{l}\text { Partly as a } \% \text { of } \\
\text { assessed annual } \\
\text { reports }\end{array}$ & Total \% \\
\hline 1 & Board and management & 13 & 0 & 0 & 2 & 100.0 & 0.0 & 0.0 & 100.0 \\
\hline 1.1 & Strategic goals & 13 & 0 & 0 & 2 & 100.0 & 0.0 & 0.0 & 100.0 \\
\hline 1.2 & Skills, knowledge and experience & 12 & 1 & 0 & 2 & 92.3 & 7.6 & 0.0 & 100.0 \\
\hline 1.3 & Limit of authority & 13 & 0 & 0 & 2 & 100.0 & 0.0 & 0.0 & 100.0 \\
\hline 1.4 & Ethical conduct & 10 & 1 & 2 & 2 & 76.9 & 7.7 & 15.4 & 100.0 \\
\hline 2.1 & Executive & 13 & 0 & 0 & 2 & 100.0 & 0.0 & 0.0 & 100.0 \\
\hline 2.2 & Non-executive & 13 & 0 & 0 & 2 & 100.0 & 0.0 & 0.0 & 100.0 \\
\hline 3 & Separation of power & 13 & 0 & 0 & 2 & 100.0 & 0.0 & 0.0 & 100.0 \\
\hline 4 & Appointment and tenure of board members & 9 & 2 & 2 & 2 & 69.2 & 15.4 & 15.4 & 100.0 \\
\hline 5 & Board committees & 13 & 0 & 0 & 2 & 100.0 & 0.0 & 0.0 & 100.0 \\
\hline 6 & Board meetings & 12 & 0 & 1 & 2 & 92.3 & 0.0 & 7.6 & 100.0 \\
\hline 7 & Remuneration & 12 & 1 & 0 & 2 & 92.3 & 7.7 & 0.0 & 100.0 \\
\hline 7.2 & Other emoluments & 13 & 0 & 0 & 2 & 100.0 & 0.0 & 0.0 & 100.0 \\
\hline 8 & Board appraisal & 11 & 1 & 1 & 2 & 84.6 & 7.6 & 7.6 & 100.0 \\
\hline 9 & Rights and functions of shareholders & 8 & 2 & 3 & 2 & 61.5 & 15.4 & 23.1 & 100.0 \\
\hline 10 & Equity ownership & 13 & 0 & 0 & 2 & 100.0 & 0.0 & 0.0 & 100.0 \\
\hline 11 & Protection of shareholders' rights & 9 & 2 & 2 & 2 & 69.2 & 15.4 & 15.4 & 100.0 \\
\hline 12 & General meeting & 13 & 0 & 0 & 2 & 100.0 & 0.0 & 0.0 & 100.0 \\
\hline 13 & Shareholders' association & 3 & 8 & 2 & 2 & 23.1 & 61.5 & 15.4 & 100.0 \\
\hline 14 & Rights of other stakeholders & 13 & 0 & 0 & 2 & 100.0 & 0.0 & 0.0 & 100.0 \\
\hline 15 & Disclosure and transparency & & & & & & & & \\
\hline 15.1 & Accounting estimates & 13 & 0 & 0 & 2 & 100.0 & 0.0 & 0.0 & 100.0 \\
\hline 15.2 & Governance structure & 13 & 0 & 0 & 2 & 100.0 & 0.0 & 0.0 & 100.0 \\
\hline 15.3 & Risk assets & 13 & 0 & 0 & 2 & 100.0 & 0.0 & 0.0 & 100.0 \\
\hline 15.4 & Regulatory contraventions & 12 & 1 & 0 & 2 & 92.3 & 7.6 & 0.0 & 100.0 \\
\hline 15.5 & Sanctions and penalties & 12 & 1 & 0 & 2 & 92.3 & 7.6 & 0.0 & 100.0 \\
\hline 16.2 & External auditors & 13 & 0 & 0 & 2 & 100.0 & 0.0 & 0.0 & 100.0 \\
\hline 16.3 & Chief Compliance Officer & 13 & 0 & 0 & 2 & 100.0 & 0.0 & 0.0 & 100.0 \\
\hline 17 & Whistle-blowing & 11 & 0 & 2 & 2 & 84.6 & 0.0 & 15.4 & 100.0 \\
\hline 18 & Risk management & 13 & 0 & 0 & 2 & 100.0 & 0.0 & 0.0 & 100.0 \\
\hline
\end{tabular}

Discount Houses in Nigeria and Guidelines for Whistle Blowing in Nigeria Banking Industry for the year ended ... (Sterling Bank 2015: 124, 2016:138)

Sterling Bank Plc according to the directors appears to attain 100\% compliance in 2015 and 2016 on whistle-blowing policy.

In addition to what appears to be an endorsement of its corporate governance practices by a corporate governance rating agency, the board of Sterling Bank reported in 2017 that the Bank was conferred with the 'Service Excellence Award' by the Institute for Service Excellence and Good Governance for its commitment to best practice in corporate governance. The board further reported that the external auditor of the bank performed non-audit services for the bank in 2017, and the directors were of the view that the provision of the services did not impair the independence and objectivity of the external auditor. The position of the directors appears contradictory to commended best practices.

The consultants of Access Bank Plc, Citi Bank and GT Bank $\mathrm{Plc}$ were very impressed with the performance of the board of directors on corporate governance and commended them in their report. The report of Access Bank Plc (2016) states:

It is our opinion that the Board demonstrated understanding of responsibilities stated in the Central Bank of Nigeria's Code of Corporate Governance and complied with the Company's Governance arrangements and requirements of the Central Bank of Nigeria's Code of Corporate Governance. (p. 21)

Citi Bank (2016) report states that:

... the Board of Directors continued to ensure that high standards of corporate governance were maintained in the Bank. In the area of gender balancing, the Board has made giant strides over the years in increasing the number of women on the Board, in line with Citi's commitment to diversity and female empowerment. (p. 13)

On the other hand, the consultant that evaluated GT Bank Plc (2016) reported that:

Overall, we observed that Guaranty Trust Bank Plc's corporate governance as a practice is maturing towards the advanced stage. The Board has integrated its policies across the entire Group and also embedded the best practices on good corporate governance. (p. 70) 
It appears that Ecobank agreed that there were corporate governance lapses in the bank at the time despite alluding to the significance of corporate governance as the cornerstone of the bank's business operations (Ecobank Plc 2014). However, the bank reported in 2015 and 2016 that 'there has been considerable improvement in the Group's corporate governance practices' (Ecobank Plc 2016:40).

On its part, Union Bank of Nigeria consistently asserted in its 2015, 2016 and 2017 annual reports that:

The Bank is committed to the highest ethical standards and transparency in the conduct of its business. (Union Bank of Nigeria Plc 2015: 4, 2016:6, 2017: 6)

Some of the banks also acknowledged in their annual reports that there were challenges in compliance with the codes, which may lead to compliance with the letters rather than embracing the spirit of the code, consequently defeating the purpose of the code. Access Bank Plc (2017) stated that:

Board must demonstrate that good corporate governance is not a box-ticking exercise by setting the right ethical tone from the top. (p. 118)

One of the factors that encourage boxticking is the situation when compliance is perceived as an end in itself rather than as part of a process to achieve a company's objectives as well as to ensure sustainability. GT Bank Plc (2014) states in its 2014 annual report that:

[C]orporate governance is not an end in itself but an essential enabler for value creation whilst propagating a values-led culture, high behavioural standards and robust procedures as fundamental tools in the entrenchment of a strong corporate governance framework. (p. 11)

First Bank Plc, in its 2014 annual report, reiterates the need for corporate governance to be completed by an ethical board, where directors 'are persons of integrity, willing to comply not just with the letter of the Codes, but also with its spirit' (FBN Plc 2014:162). The bank further demonstrated its commitment to embracing the spirit of the corporate governance code in its 2016 annual report. FBN Plc (2016) stated that:

It is not enough to pay lip service to the observation of good corporate governance practices as a compliance-ticking exercise; it has to be demonstrated that there is resolute belief in the principles and ways of conducting business by members of the Board, both collectively and individually. (p. 128)

\section{Stanbic IBTC Plc (2015) stated:}

SBG's board of directors remains steadfast in implementing governance practices that comply with international best practice, where substance prevails over form. (p. 52)

It was observed that banks with international licences embraced corporate governance policies beyond the statutory requirements of CAMA, BOFIA, CBN and SEC codes by adopting principles found in the United Kingdom and South Africa codes of corporate governance. For example, the external consultant engaged by FBN Plc for the appraisal of corporate governance status of the bank reported that their work approach, apart from incorporating the expectations of the extant legal and institutional corporate governance framework in Nigeria, included the principles enshrined in King Report on Corporate Governance (South Africa) and the UK Corporate Governance Code as a basis for forming an opinion on the corporate governance status of the bank. FBN Plc (2014) also reported in 2014 that it was commended by the $\mathrm{CBN}$ in its joint examination report with the Nigeria Deposit Insurance Corporation (NDIC) where it was noted that:

FBN Holdings Plc met and exceeded the corporate governance standards expected of a financial holding company despite the absence of regulations and guidelines. (p. 44)

GT bank reported that beyond the disclosure requirements of SEC and CBN codes, its disclosures comply with the requirements under the Disclosure and Transparency Rules of the Financial Conduct Authority (FCA) (United Kingdom), which are applicable to non-United Kingdom companies with Global Depositary Receipts (GDRs) listed on the London Stock Exchange (GT Bank 2014).

An area where some banks surpass the provision of the code is the appointment of independent directors. The SEC code prescribes the appointment of one independent director on the board, whilst the $\mathrm{CBN}$ code requires banks to have at least two independent directors. FBN appointed two independent directors to the board, apparently exceeding the requirements of the SEC code. According to the bank, the appointment resulted in more independence for the board, thus underscoring what the bank also described as its 'resolve to meet and exceed regulatory and global corporate governance demands' (FBN 2014 Plc p.162). Whilst FBN exceeded the one independent director provision of the SEC code in 2014, GT bank reported in 2017 that it appointed three nonexecutive independent directors. These directors do not have any significant shareholding interest or any special business relationship with the bank. UBA also reported in 2017 that the bank had four independent directors.

Whilst the majority of the banks did not give details of the recommendations of the evaluating consultants in the annual report, GT bank reported in its 2014 annual report that the key areas that needed improvement were the board's oversight of sustainability issues, the enhancement of the existing process for the declaration of directors' interests and performance management process for executive directors.

\section{Conclusion}

Corporate governance is concerned with observance of best practices. This article examined the trend of disclosure of corporate governance practices by Nigerian banks in their annual reports from 2014 to 2017, when the code of corporate governance mandatory for banks and discount houses in Nigeria became effective. The article used the qualitative content analysis method to investigate the extent of compliance with the statutory and regulatory requirements and how these were reported in the annual reports of the banks. 
The analysis of the disclosures of the information in the annual reports shows substantial compliance with the provisions of the CBN code and other regulatory requirements by the banks. The result is a departure from previous studies on disclosure in developing countries, which concludes that disclosure levels are generally low (Tsamenyi et al. 2007). Two corporate governance pillar scores, rights and functions of shareholders and engagement of shareholders' association received little or no attention in the assessed annual reports of the banks. However, the corporate governance status of the banks and board evaluation reports required by the SEC and CBN codes to be conducted by an external consultant for the banks also indicated substantial compliance for the banks covered in the content analysis. The study concludes that banks tend to do well when it comes to disclosures of corporate governance practices in their annual reports. Although the article did not investigate whether compliance with disclosure was 'technical compliance' (Nakpodia et al. 2018) or a desire to embrace the spirit of the disclosure requirements, however, it draws the attention of regulators and other stakeholders to the fact that addressing corporate governance challenges in emerging economies should look beyond compliance with disclosure requirements and begin to focus on other measures such as how board of directors can provide ethical leadership.

\section{Acknowledgements}

This manuscript was written from the data that was collected as part of the $\mathrm{PhD}$ study by the authors.

\section{Competing interests}

Authors are not conflicted.

\section{Authors' contributions}

O.O. conceptualised, collected, analysed data. T.M. supervised the collection and the analysis of data. T.M. also reviewed and finalised the manuscript.

\section{Funding information}

This research received no specific grant from any funding agency in the public, commercial or not-for-profit sectors.

\section{Data availability statement}

Data sharing is not applicable to this article as no new data were created or analysed in this study.

\section{Disclaimer}

The views and opinions expressed in this article are those of the authors and do not necessarily reflect the official policy or position of any affiliated agency of the authors.

\section{References}

Access Bank Plc, 2016, Annual report and accounts, viewed 11 August 2018, from https://www.accessbankplc.com/pages/Investor-Relations/financial-reports/ Annual-Reports.aspx
Adegbite, E., 2015, 'Good corporate governance in Nigeria: Antecedents, propositions and peculiarities', International Business Review 24(2), 319-330. https://doi. org/10.1016/j.ibusrev.2014.08.004

Ahunwan, B., 2002, 'Corporate governance in Nigeria', Journal of Business Ethics 37(3), 269-287. https://doi.org/10.1023/A:1015212332653

Akhtaruddin, M., Hossain, M.A., Hossain, M. \& Yao, L., 2009, 'Corporate governance and voluntary disclosure in corporate annual reports of Malaysian listed firms', Journal of Applied Management Accounting Research 7(1), 1

Bank for International Settlements (BIS), 2015, Basel Committee on Banking Supervision: Guidelines - Corporate governance principles for banks, viewed 27 August 2017, from https://www.bis.org/bcbs/publ/d328.htm

CBN, 1998, Banking Supervision Annual Report, viewed 18 October 2017, from https://www.cbn.gov.ng/Documents/bsdreports.asp

CBN, 2006, Bank Supervision Annual Report, viewed 17 September 2017, from https:// www.cbn.gov.ng/Documents/bsdreports.asp

CBN, 2008, Bank Supervision Annual Report, viewed 17 September 2017, from https:// www.cbn.gov.ng/Documents/bsdreports.asp

CBN, 2010, Prudential guidelines for deposit money banks in Nigeria, viewed 11 February 2019, from https://www.cbn.gov.ng/out/2010/publications/bsd/prudentialguidelines. pdf

CBN, 2011, Bank Supervision Annual Report, viewed 18 September 2017, from https:// www.cbn.gov.ng/Out/2012/publications/reports/rsd/arp-2011

CBN, 2013, Bank Supervision Annual Report, viewed 18 September 2017, from https:// www.cbn.gov.ng/documents/annualreports. asp?beginrec $=141$ \&endrec $=154$

CBN, 2014, Code of corporate governance for banks and discount houses in Nigeria, viewed 29 August 2016, from https://www.cbn.gov.ng/out/2014/fprd/circular.pdf

CBN, 2015, Bank Supervision Annual Report. Accessed 20 September 2017, from https://www.cbn.gov.ng/Documents/annualreports.asp?beginrec $=21 \&$ endrec $=40$

Citibank Nigeria Limited, 2016, Annual report, viewed 11 August 2018, from https:// www.citigroup.com/citi/about/countries-and-jurisdictions/nigeria.html

Citibank Nigeria Limited, 2017, Annual report, viwed 11 August 2018, from https:// www.citigroup.com/citi/about/countries-and-jurisdictions/nigeria.html

Commonwealth Association for Corporate Governance (CACG), 1999, CACG Guidelines: Principles for Corporate Governance in the Commonwealth: Towards Global Competitiveness and Economic Accountability, viewed 10 October 2017, from http://www.ecseonline.com/PDF/CACG Guidelines-Principles for Corporate Governance in the Commonwealth.pdf

Drisko, J.W. \& Maschi, T., 2016, Content analysis. Pocket guide to social work research methods, Oxford University Press, New York, NY.

Ecobank Plc, 2014, Annual report, viewed 11 August 2018, from https://ecobank.com/ upload/publication/20160607015116375F6KRSS7YPK/201506180747401989953 EexagDPBd.pdf

Ecobank Plc, 2016, Annual report, viewed 11 August 2018, from https://ecobank.com/ upload/publication/20170612044513823B6SH5UBR32/201706120445053059. pdf

Egbo, O.P., 2012, 'Universal basis of bank failure-The Nigeria case', Developing Country Studies 2(10), 2012.

Elo, S. \& Kyngäs, H., 2008, 'The qualitative content analysis process', Journal of Advanced Nursing 62(1), 107-115.

First Bank of Nigeria Limited, 2014, Annual report and accounts, viewed 12 August 2018 from https://www.fbnholdings.com/wp- content/uploads/2014/02/FBN_Holdings Plc_2014_Annual_Report.pdf

First Bank of Nigeria Limited, 2017, Annual report and accounts, viewed 12 August 2018, from https://www.fbnholdings.com/wp- content/uploads/2018/04/FBN_Holdings_ Plc_2017_Annual_Report.pdf

Ho, S.S. \& Wong, K.S. 2001, 'A study of the relationship between corporate governance structures and the extent of voluntary disclosure', Journal of International Accounting, Auditing and Taxation 10(2), 139-156. https://doi.org/10.1016/ S1061-9518(01)00041-6

Institute of Directors, 2016, King IV Report on Corporate Governance for South Africa, viewed 20 July 2017, from https://www.iodsa.co.za/page/kingllI

Jensen, M.C. \& Meckling, W.H., 1976, 'Theory of the firm: Managerial behavior, agency costs and ownership structure', Journal of Financial Economics 3(4), 305-360. https://doi.org/10.1016/0304-405X(76)90026-X

Krippendorff, K. 1980, Content analysis: an introduction to its methodology, The Annenberg School for Communication, University of Pennsylvania, Sage Publications.

Mallin, C., 2002, 'The relationship between corporate governance, transparency and financial disclosure', Corporate Governance: An International Review 10(4), 253-255. https://doi.org/10.1111/1467-8683.00289

Moloi, S.T.M., 2008, 'Assessment of corporate governance reporting in the annual reports of South African listed companies', Masters dissertation, University of South Africa.

Moloi, T., 2014, 'Leading internal and external sources of credit risk in top South African banks: Risk governance and control', Financial Markets and Institution 4(3), 51-65. https://doi.org/10.22495/rgcv4i3art6

Moloi, T., 2016a, 'Exploring risks identified, managed and disclosed by South Africa's public Higher Education Institutions (HEIS)', Journal of Accounting and Management 6(2), 55-70. https://doi.org/10.22495/rgcv4i3art6

Moloi, T., 2016b, 'The nature of credit risk information disclosed in the risk and capital reports of the top-5 South African banks', Banks and Bank Systems 11(3), 87. https://doi.org/10.21511/bbs.11(3).2016.09 
Nakpodia, F., Adegbite, E., Amaeshi, K. \& Owolabi, A., 2018, 'Neither principles nor rules: Making corporate governance work in sub-Saharan Africa', Journal of Business Ethics 151(2), 391-408. https://doi.org/10.1007/s10551-016 3208-5

Neuendorf, K.A., 2017, The content analysis guidebook, Cleveland State University, Sage, Thousand Oaks.

Organisation for Economic Co-operation and Development (OECD), 1999, Organisation for economic co-operation and development principles of corporate governance, viewed 28 June 2017, from https://www.oecd.org/officialdocuments/publicdispla ydocumentpdf/?cote=C/MIN(99)6\&docLanguage=En

OECD, 2004, Organisation for Economic Co-operation and Development principles of corporate governance, viewed 30 June 2017, from https://www.oecd.org/ corporate/ca/corporategovernanceprinciples/31557724.pdf

Organisation for Economic Co-operation and Development (OECD), 2015, G20/OECD Principles of Corporate Governance, viewed 30 June 2017, from https://www. oecd.org/corporate/principles-corporate-governance.htm

Okeahalam, C.C. \& Akinboade, O.A., 2003, 'A review of corporate governance in Africa: Literature, issues and challenges', Global Corporate Governance Forum 15(1), 1-34.

Olaniyan, A., 2005, Corruption and economic development: How Nigeria was underdeveloped by its elite, Woodhaven Nigeria Ltd., Lagos.

Osemeke, L. \& Adegbite, E., 2016, 'Regulatory multiplicity and conflict: Towards a combined code on corporate governance in Nigeria', Journal of Business Ethics 133(3), 431-451. https://doi.org/10.1007/s10551-014-2405-3

Punch, 2016, Breaking: CBN takes over Skye Bank, viewed 13 October 2016, from https://punchng.com/breaking-cbn-takes-skye-bank/.

Ramsay, I. \& Hoad, R., 1997, 'Disclosure of corporate governance practices by Australian listed companies', Company and Securities Law Journal 15(8), viewed 11 October 2019, from https://ssrn.com/abstract=922779.

Sanusi, L.S., 2010, 'The Nigerian banking industry: What went wrong and the way forward', Convocation lecture delivered at the Annual Convocation Ceremony, Bayero University, Kano, 26 February 2010.
Securities and Exchange Commission, 2011, Code of corporate governance for public companies in Nigeria, viewed 04 August 2017, from https://sec gov.ng/code-ofcorporate-governance-for-public-companies_may-12-2014

Solomon, J., 2007, Corporate governance and accountability, John Wiley \& Sons, NJ.

Soludo, C.C., 2004, 'Consolidating the Nigerian banking industry to meet the development challenges of the 21st century', Delivered to the Special Meeting of the Bankers' Committee, 06 July 2004 at the CBN Headquarters, Abuja.

Stanbic IBTC Holdings Plc, 2017, Annual report, viewed 11 August 2018, from https:// thevault.exchange/?get_group_doc=635/1589529502-2017AnnualReportStanbiclBTCHoldingsPLC.pdf

Stemler, S., 2001, 'An overview of content analysis', Practical Assessment, Research \& Evaluation 7(17), 137-146.

Sterling Bank Plc, 2015, Report of the directors and statutory audit committee and audited financial statements with independent auditors' report, viewed 08 August
2018 , from https://sterling.ng/wp- content/uploads/2019/03/44_Sterling Bank_1H_2015_Audited_Results-1.pdf

Sterling Bank Plc, 2016, Report of the directors and statutory audit committee and consolidated and separate financial statements with independent auditors' report, viewed 08 August 2018, from https://sterling.ng/wp-content/ uploads/2019/03/42_Sterling-bank-Audited-Account-2016.pdf

Tsamenyi, M., Enninful-Adu, E. \& Onumah, J., 2007, 'Disclosure and corporate governance in developing countries: Evidence from Ghana', Managerial Auditing Journal 22(3), 319-334. https://doi.org/10.1108/02686900710733170

Union Bank of Nigeria Plc, 2015, Annual report, viewed 13 August 2018, from https:// www.unionbankng.com/wp-content/uploads/2019/07/Union-Bank-Plc-AuditedFinancial-Statements-as-at-December-2015.pdf

Union Bank of Nigeria Plc, 2017, Annual report, viewed 13 August 2018, from https:// www.unionbankng.com/wp-content/uploads/2019/07/FY-2017-IFRS-FinancialStatement.pdf

Weber, R.P., 1990, Basic content analysis, 2nd edn., Sage, Newbury Park, CA.

Yoshikawa, T. \& Rasheed, A.A., 2009, 'Convergence of corporate governance: Critical review and future directions', Corporate Governance: An International Review 17(3), 388-404. https://doi.org/10.1111/j.1467-8683.2009.00745.x 


\section{Appendix 1: Questions on the checklist used in the assessment of corporate governance disclosures in the annual reports of Nigerian banks}

Name of bank

\section{Board and management}

Does the annual report of a bank contain the following information?

1.1 The responsibilities of the board?

\begin{tabular}{|c|c|c|} 
Yes & No & Partly \\
\hline
\end{tabular}

1.2 The board size?

\begin{tabular}{l|l|l} 
Yes & No & Partly
\end{tabular}

1.3 The board composition?

\begin{tabular}{c|c|c} 
Yes No & No Partly
\end{tabular}

1.4 Skill, knowledge and experience of directors?

\begin{tabular}{|c|c|c|} 
Yes & No & Partly
\end{tabular}

1.5 Independence of the board from executive management?

\begin{tabular}{c|c|c} 
Yes & No & Partly
\end{tabular}

1.6 Appointment and tenure board members?

\section{Board committees}

Does the annual report of a company contain information relating to board committees such as the following?

2.1 Information relating to the audit committee

\begin{tabular}{|c|c|c|} 
Yes No & Nortly
\end{tabular}

2.2 Information relating to the remuneration committee

\begin{tabular}{|c|c|c} 
Yes No & Partly \\
\hline
\end{tabular}

2.3 Information relating to bank risk management committee

Yes No Partly

2.4 Information relating to other board committees

Yes

No

No

Partly

3. Board meetings

3.1 Does the annual report contain information relating to the number of meetings held by the board of directors?

\begin{tabular}{c|c|c} 
Yes & No & Partly
\end{tabular}




\section{Remuneration policy}

4.1 Does the annual report contain information on the structure of remuneration, that is, salaries, fees and other emoluments?

\begin{tabular}{|l|l|r} 
Yes & No & Partly
\end{tabular}

\section{Board appraisal}

5.1 Is the report of the external consultant disclosed in the annual report?

\begin{tabular}{|l|l|l|} 
Yes & No & Partly
\end{tabular}

\section{Rights and function of shareholders}

6.1 Does the annual report of the bank contain the information regarding shareholders' participation in bank activities (shareholders' voting powers)?

\begin{tabular}{|c|c|c|} 
Yes & No & Partly \\
\hline
\end{tabular}

Does the annual report of the bank clearly outline the duties and powers of its shareholders?

\section{Equity ownership}

7.1 Does the annual report of the bank show the shareholding of the directors?

\begin{tabular}{|l|l|r} 
Yes & No & Partly
\end{tabular}

7.2 Does the annual report show the major shareholders of the bank?

$$
\text { Yes }
$$

\section{Protection of shareholders' right}

8.1 Does the annual report contain information that every shareholder is treated fairly?

8.2 Does the annual report disclose information that minority shareholders are adequately protected from overbearing influence of controlling shareholders?

\begin{tabular}{|l|l|r} 
Yes & No & Partly \\
\hline
\end{tabular}

\section{General meetings}

9.1 Does the annual report contain information on notice of general meetings and venue?

\begin{tabular}{l|l|c|} 
Yes & No & Partly \\
\hline
\end{tabular}

9.2 Does the annual report disclose agenda that clearly set out statutory business and substantial resolutions proposed for consideration at general meetings?

\begin{tabular}{|c|c|c|} 
Yes No & No & Partly
\end{tabular}

\section{Shareholders' association}

Does the annual report disclose information about its interaction with shareholders' associations?

\begin{tabular}{|l|l|r} 
Yes & No & Partly
\end{tabular}




\section{Rights of other stakeholders}

11.1 Does the annual report contain information that stakeholders are able to freely communicate their concerns about illegal or unethical practices to the board?

\begin{tabular}{|c|c|c|}
\hline Yes & No & Partly \\
\hline
\end{tabular}

11.2 Does the annual report disclose information that stakeholders have the opportunity to obtain effective redress for violation of their rights?

$$
\text { Yes }
$$

No

Partly

11.3 Does the annual report contain information that the bank demonstrates good sense of social responsibility to its stakeholders, such as customers, employees, host communities and the general public?

\begin{tabular}{|c|c|c} 
Yes & No & Partly
\end{tabular}

\section{Disclosure and transparency}

Does the annual report disclose major items that have been estimated in accordance with applicable accounting and auditing standards, rationale for all material estimates, details on directors, corporate governance, risk assets and risk management?

Yes

No

Partly

\section{Transparency and integrity reporting}

13.1 Does the annual report contain information that the bank has a structure to independently verify and safeguard the integrity of its financial reporting that entails the review and consideration of the financials by the Board Audit Committee, as well as enhance the independence and competence of the bank's external auditors?

\begin{tabular}{l|c|c} 
Yes & No & Partly \\
\hline
\end{tabular}

13.2 Does the annual report disclose information that the Board Audit Committee is structured in such a way that it consists only of nonexecutive directors who are financially literate to read and understand financial statements, has at least three members and is chaired by an independent director?

$$
\text { Yes }
$$

No

Partly

\section{Whistle-blowing policy}

14.1 Does the annual report contain information that the bank has a whistle-blowing policy made known to the employees and other stakeholders?

\begin{tabular}{|l|l|l} 
Yes & No & Partly
\end{tabular}

14.2 Is there any indication that the whistle-blowing policy contains mechanisms, including assurance of confidentiality, that encourage all stakeholders to report any unethical activity to the bank and the CBN as may be required by regulation?

\begin{tabular}{|c|c|c|}
\hline Yes & No & Partly \\
\hline
\end{tabular}

\section{Risk management}

15.1 Does the annual report contain information that the bank has a risk management framework, specifying the governance architecture, policies, procedures and processes for the identification, measurement, monitoring and control of the risks inherent in its operations?

\begin{tabular}{|c|c|c|}
\hline Yes & No & Partly \\
\hline
\end{tabular}

15.2 Does the risk management policies disclosed in the annual report reflect the bank's risk profile and appetite, as well as all elements of risk management and internal control systems?

Yes

No

No

Partly 


\section{Appendix 2: Corporate governance pillar scores for content analysis}

\begin{tabular}{|c|c|}
\hline Categories of corporate governance practices mandated by the CBN code & Subcategories \\
\hline 1. Board and management & $\begin{array}{l}\text { - Strategic goals } \\
\text { - Skills, knowledge and experience } \\
\text { - Limit of authority } \\
\text { - Ethical conduct }\end{array}$ \\
\hline 2. Size and composition of board & - Executive and non-executive directors \\
\hline 3. Separation of power & - Chairman \\
\hline 4. Appointment and tenure of board members & - Tenure \\
\hline 5. Board committees & - Committees \\
\hline 6. Board meetings & - Meetings \\
\hline 7. Remuneration policy & $\begin{array}{l}\text { - Fees } \\
\text { - Reimbursable expenses } \\
\text { - Stock option }\end{array}$ \\
\hline 8. Board appraisal & - Board appraisal \\
\hline 9. Rights and functions of shareholders & - Shareholders \\
\hline 10. Equity ownership & - Share capital \\
\hline 11. Protection of shareholders rights & - Shareholders \\
\hline 12. General meeting & - Meetings \\
\hline 13. Shareholder association & - Association \\
\hline 14. Rights of other stakeholders & $\begin{array}{l}\text { - Stakeholders } \\
\text { - Social responsibilities }\end{array}$ \\
\hline 15. Disclosure and transparency & $\begin{array}{l}\text { - Accounting estimates } \\
\text { - Governance structure } \\
\text { - Risk assets } \\
\text { - Regulatory contraventions } \\
\text { - Sanctions and penalties }\end{array}$ \\
\hline 16. Transparency and integrity reporting & $\begin{array}{l}\text { - Audit committee } \\
\text { - External auditors } \\
\text { - Chief Compliance Officer }\end{array}$ \\
\hline 17. Whistle-blowing policy & - Whistle-blowing \\
\hline 18. Risk management framework & - Risk management \\
\hline
\end{tabular}

Source: CBN, 2014, Code of corporate governance for banks and discount houses in Nigeria, viewed 29 August 2016, from https://www.cbn. gov.ng/out/2014/fprd/circular.pdf 


\section{Appendix 3: Spreadsheet for recording corporate governance disclosures in annual reports of Nigerian banks}

\begin{tabular}{|c|c|c|c|c|c|c|}
\hline $\begin{array}{l}\text { Corporate } \\
\text { governance } \\
\text { pillar score }\end{array}$ & Keywords & $\begin{array}{c}\text { Disclosed in } \\
\text { the annual } \\
\text { report? }\end{array}$ & $\begin{array}{l}\text { Page number } \\
\text { where the } \\
\text { information is } \\
\text { disclosed }\end{array}$ & $\begin{array}{l}\text { Is the corporate governance } \\
\text { principle discussed in } \\
\text { sentence, paragraph } \\
\text { of pages? }\end{array}$ & $\begin{array}{l}\text { Quantification of } \\
\text { the pillar score, } \\
\text { that is, number of } \\
\text { directors }\end{array}$ & $\begin{array}{l}\text { In which section of } \\
\text { the annual report is } \\
\text { the information? }\end{array}$ \\
\hline & & & & & & \\
\hline & & & & & & \\
\hline & & & & & & \\
\hline & & & & & & \\
\hline & & & & & & \\
\hline & & & & & & \\
\hline & & & & & & \\
\hline & & & & & & \\
\hline & & & & & & \\
\hline & & & & & & \\
\hline & & & & & & \\
\hline & & & & & & \\
\hline & & & & & & \\
\hline
\end{tabular}




\section{Appendix 4: Deposit money banks in Nigeria as of 31 December 2017}

A. Deposit money banks with international authorisation in Nigeria

1. Access Bank Plc

2. Diamond Bank Plc

3. Fidelity Bank Plc

4. First City Monument Bank Plc

5. First Bank of Nigeria Plc

6. Guaranty Trust Bank Plc

7. Skye Bank Plc

8. Union Bank Plc

9. United Bank for Africa Plc

10. Zenith Bank Plc

\section{B. Deposit money banks with national authorisation in Nigeria}

1. Citi Bank Nigeria Limited

2. Ecobank Nigeria Plc

3. Heritage Banking Company Limited

4. Keystone Bank Limited

5. Stanbic IBTC Bank PIC

6. Standard Chartered Limited

7. Sterling Bank Plc.

8. Unity Bank Plc

9. Wema Bank Plc

\section{Deposit money banks with regional authorisation in Nigeria}

1. SunTrust Bank Nigeria Limited

2. Providus Bank Limited

\section{Non-interest banks in Nigeria}

1. Jaiz Bank Plc

\section{E. Merchant banks in Nigeria}

1. Coronation Merchant Bank

2. FBN Merchant Bank

3. FSDH Merchant Bank

4. Rand Merchant Bank

5. Nova Merchant Bank 